\title{
Educating the academic librarian as a blended professional: a review and case study
}

\author{
Sheila Corrall \\ Information School, University of Sheffield, Sheffield, UK.
}

\begin{abstract}
Purpose - Explores the phenomenon of the hybrid information specialist in the academic library setting in relation to curriculum development for preparatory and continuing professional education for librarianship with particular reference to the contemporary iSchools movement.

Design/methodology/approach - Reviews trends and developments in academic information services and the information science academy in the context of continuing technological advances and educational change. Presents a case study of curriculum development and portfolio renewal, using the specialist roles of digital library manager and information literacy educator to show how the principles of interactive planning can be applied in articulating an academic strategy to meet the changing demands of educational institutions, professional bodies and employers.

Findings - There are significant parallels between professional education and professional practice in the shifting boundaries, expanded portfolios and challenged identities evident in the current information marketplace. A combination of continuous incremental development with periodic fundamental review enables professional educators to meet the changing mandates of different stakeholder groups. When combined with a strong professional focus, the breadth and depth of multidisciplinary expertise found in a research-led iSchool facilitates the design of specialised pathways and programmes for practitioners moving into blended roles.

Practical implications - Practitioners intent on careers in academic libraries should consider the opportunities and demands of hybrid blended roles when choosing educational programmes and pathways.

Originality/value - Provides a conceptual framework to illustrate the nature of emergent professional roles and current challenges facing professional educators. Uses Ackoff's interactive planning theory to illuminate the problem of academic planning in complex pluralist contexts.
\end{abstract}

Keywords Academic libraries, Blended librarians, Continuing education, Hybrid professionals, iSchools, Professional education.

Paper type Case study

\section{Introduction}

The challenges and opportunities facing academic librarians are continually changing as changes occur in the operating environment at both global and institutional levels. Key trends affecting their roles and skills include convergence of academic services, combining libraries with IT and/or other learning support services; awareness of information literacy and recognition of the teaching role of librarians; and a maturing role in institutional repository management and its suggested extension to research data management. The increasingly specialised nature of their work is reflected in the use of terms such as 'para-academic', hybrid librarian' and 'blended professional' to highlight their boundary-spanning activities and identities. 
The challenges and opportunities facing professional educators are similarly fluid. Professional education for librarians has to anticipate changes and developments in professional tasks, roles and expectations, both at the macro level of the profession as a whole and the micro level of different library specialties. Education programmes must take account of standards set by national and international professional bodies, in addition to reflecting the realities of professional work in the sector. Programme content should also be informed by research in the discipline, enabling the academy to influence professional thinking and practice, contributing to the development and positioning of the profession. The challenges facing educators are significant, with some employers and graduates questioning the value of academic preparation for professional practice, while others see both initial and continuing education as a worthwhile investment, but want flexible tailored provision, not just a standard offer. Educators are also struggling with their own disciplinary identities and relationships.

The Sheffield Information School has been providing education for librarianship since 1963, with a strong record in preparing graduates for academic libraries. The curriculum has developed in tandem with environmental changes, research discoveries, teaching innovations and practitioner feedback. New topics and electives have been added, new qualifications have been introduced at different levels and new programmes have been created for experienced practitioners wanting to enhance their skills and careers. New methods of teaching and assessment have been implemented, moving activities in the classroom or laboratory and assignments for individuals and groups closer to the real-world tasks undertaken in the workplace. In 2009 Sheffield initiated a fundamental review of its generalist and specialised library and information programmes, in an effort to simplify provision, improve access for part-time students and meet the needs of professionals interested in emergent specialist roles. The review has raised questions about the nature of our discipline and profession, including issues around core competence, professional identity, service contexts and career paths that are relevant to all librarians.

This paper uses the concept of the blended professional to focus a review of the evolving roles of academic librarians and discussion of their professional education. It reviews the evolution, identification and differentiation of hybrid specialist roles in academic libraries through the literature and then reviews the evolution and differentiation of professional education during the hybrid library era. The review of the literature suggests the need for an interactive planning model to support the strategic development of professional curricula in dynamic environments, enabling continual adjustment of module and programme content and delivery to meet changing needs and demands, but also encouraging periodic review of the total portfolio to identify potential overlaps and synergies. The paper concludes with a case study of the Sheffield iSchool, showing how a combination of continuous and holistic planning have supported the development of specialist modules, programmes and pathways that together offer a range of initial and continuing education options for academic librarians interested in developing careers as digital library managers or information literacy educators.

\section{Literature review}

Recognition of boundary-spanning information activities

Commentators have used terms such as 'para-academic roles', 'hybrid librarians' and 'blended professionals' to flag the boundary-spanning nature of academic library work in the networked information environment and highlight the need for an extended skill set covering other related domains (Allen, 2005; Bell and Shank, 2004; Corrall and Lester, 1996; Fowell 
and Levy, 1995; Garrod, 1999; Law, 2009). The term 'blended professional' has been used in higher education for a specialist spanning professional and academic domains (Whitchurch, 2008) and similarly in secondary education, where it has been applied to school librarians (Sitter et al., 2009). In the academic library sector, the 'blended librarian' has been conceived as a professional combining the skillset of librarianship with information technology and educational design (Bell and Shank, 2004).

The origins of hybrid jobs can be traced back to the 1980s. Although hybrid roles can exist in any environment, the concept is particularly associated with technological developments in information-intensive organisations. Earl and Skyrme (1992) discuss the need to develop people with both information technology skills and business/organisational knowledge (by developing the business acumen and organisational of IT professionals or developing the technological competence of professionals from other backgrounds). Earl (1989: 205) originally defined hybrids as 'people with technical skills able to work in user areas doing a line or functional job, but adept at developing and implementing IT application ideas', identifying the hybrid professional more clearly as a professional with expertise in and connections to two areas, akin to the departmental computer officer in a university or the subject specialist or liaison librarian in our own field. In the academic library world, hybridity tends to be linked to the notion of the 'hybrid library' that delivers both traditional paper-based materials and electronically-mediated resources, which was promoted by the UK Electronic Libraries Programme (eLib), whose director is generally credited with inventing the term (Rusbridge, 1998).

A key worldwide trend associated with technological developments in the eLib period is the formulation of integrated institution-wide information strategies (Allen and Wilson, 1996; Bernbom, 1998; Breaks, 1991; Hughes, 1997; Michalko, 2000; Sidgreaves, 1989) along with the creation of new organisational models for academic library, computing/information technology and other support services, typically referred to as 'converged', 'merged' or 'integrated' services (Ferguson, 2000; Field, 2001; Hanson, 2005; Hirshon, 1998; McKnight, 2002; Sayers, 2001). These models combine distinct but related activities in unified organisational structures and/or bring services together through collaborative operational delivery. Service convergence has also been reflected in new physical environments to support learning and research in the digital world, with college and university libraries being transformed into technology-rich spaces and changing their names to 'learning centres', 'information commons', 'learning commons' or similar (Beagle, 1999; Beatty and White, 2005; Creth and Lowry, 1994; Crockett et al., 2002; Oyston, 2004; Sinclair, 2009). Spaces of this type provide the kind of environment where hybrid species are born and flourish (Levy and Roberts, 2005; Norry, 2004; Sinclair, 2009).

\section{Evolution of hybrid information jobs}

Discussion and development of hybrid library roles, including both library/computing and library/learning blends, can be traced back to the same era. Fowell and Levy (1995: 274) report 'the emergence of a para-academic role for the subject/information librarian, entailing greater involvement in facilitation of, and support for, resource-based open learning, confirming predictions of the Fielden report (JFC, 1993: para. 4.13), which forecast 'A major para-academic role for [academic library] staff... as the initial mediators and facilitators of resource-based open learning, with responsibilities for first-line instruction and supervision of students'. In the US, Cimbala (1987) explored the need for the 'hybrid librarian-computer scientist' in relation to the concept of the 'scholarly information center' in the (new) electronic environment and Woodsworth et al. (1992) argued that there were so many 
common elements and so few distinctions among the jobs of library and computing staff that we should be thinking in terms of one 'information job family', rather than two staff categories. However, Sutherland's (1992) UK study dismissed the notion of a 'hybrid [library/IT] member of staff' on the basis that its popularity had waned and it had not materialised in practice.

Towards the end of this decade, Garrod (1999: 187), writing in the context of the eLib programme, observed

'The notion of the 'hybrid' library professional was once ruled out as a viable possibility, but is gradually gaining in acceptance as managers of academic libraries realise the networked information environment is here to stay, and a new breed of information professional is needed to support it'.

She then extends the debate around evolving roles to the 'need for new programmes of education for information professionals', identifying risks in both generalist and specialist education strategies (Garrod (1999: 188). Later, Norry (2004: 87) refers to 'hybrid roles on support desks' arising from the convergence of IT and information/library support, but driven by changes in learning and teaching, that resulted in 'broader roles, encompassing several job types which were previously undertaken by separate individuals or teams, consequently involving multi-skilling' (Norry, 2004: 60). Norry's (2004) example from Leeds Metropolitan University of Information Officers providing face-to-face support across the full range of IT and information/library facilities and resources shows how Woodsworth et al.'s (1992) vision of jobs cutting across the traditional organisational boundaries of libraries, computer/IT centres, media and other services was realised in practice.

Allen (2005) argues that changes in information needs coupled with widespread adoption of IT mean libraries need to employ 'hybrid librarians' working in cross-functional technology teams to provide information and instructional services to their client departments, indicating that previous assumptions about roles based on library/IT and media or library/learning and teaching were over-simplified, with the prospect of future roles requiring all three areas of expertise. She emphasises collaboration between librarians and technologists, but also the need for librarians 'to develop, and continually update, their technology skills and competencies', citing several studies identifying broader, more complex, multi-functional jobs, fulfilling information and/or instructional roles in a technology-based environment (Allen, 2005: 292).

\section{Identification of blended professional roles}

Although applicable to multiple combinations, the term 'hybrid' is typically used when two different things are combined, while 'blended' often signifies a mixture of three (or more) ingredients. The term 'blended professional' is gaining currency in the education sector. The Alaska School Library Handbook notes that "School librarians are "blended professionals" part teacher, part administrator, and part support staff' (Sitter et al., 2009). Law (2009) reports 'a growing number of blended professionals' within the converged Information Resources Directorate that oversees Library, IT and Learning Services at the University of Strathclyde. Writing in the context of university administration, Whitchurch (2008: 394) defines blended professionals in higher education as staff "with mixed backgrounds and portfolios, dedicated to progressing activity comprising elements of both professional and academic domains'. She links the emergence of professionals fulfilling blended or 'quasiacademic' roles to the notion of a 'third space' between professional and academic domains, 
in which the concept of administrative/professional service 'has become reoriented towards one of partnership with academic colleagues and the multiple constituencies with whom institutions interact' (Whitchurch, 2008: 378).

Whitchurch (2009: 410, 417) goes on to characterise blended professionals as people experiencing 'identity stretch', but possessing 'an ability to build common ground with a range of colleagues, internal and external to the university, and to develop new forms of professional space, knowledge, relationships and legitimacies associated with broadly-based institutional projects', noting also that this phenomenon is occurring alongside 'an increasing functional specialisation' among professionals in higher education. The identity debate in librarianship tended previously to focus on general questions around professional standing and academic status (Abbott, 1998; Hoggan, 2003), but has recently become more complex, with White (2003) suggesting a polarisation and hence a choice between 'bookman' and 'knowledge worker'. Walter (2008: 64) argues such a dichotomy is an over-simplification, articulating instead a layered model of identity for librarians fulfilling specialist functions, represented by 'the idea of teacher identity as an important facet of their broader professional identity as librarians'. Partnering and collaboration are central to Bell and Shank's (2004) concept of the 'blended librarian', which was articulated in their Blended Librarians Manifesto and launched as 'A blueprint for redefining the teaching and learning role of academic librarians'. Bell and Shank (2007: 8) define a blended librarian as:

'an academic librarian who combines the traditional skill set of librarianship with the information technologist's hardware/software skills, and the instructional or educational designer's ability to apply technology appropriately in the teachinglearning process'.

Bell and Shank (2007: 3) stress that blended librarianship is about a 'meshing of skill sets' and is thus more than multi-tasking: it is about 'combining a variety of interprofessional skills and new ways of thinking' (Bell and Shank, 2007: 150) and specifically, it is about integrating new skill sets from instructional design and information technology into librarians' practice. This particular blend of professional practice has an academic disciplinary counterpart in the emergent interdisciplinary field of 'educational informatics', which sits at the intersection of library and information science, education and computer science/information and communications technology (ICT), as a research area (and teaching domain) that is concerned with the relationships between people, information, ICT, learning and professional practice (Levy et al., 2003). The claim of educational informatics as the theoretical base for blended librarianship is reinforced by its differentiation from the 'adjacent field of educational computing' by 'the way in which it integrates the central concerns of librarianship and information science' (Levy, 2008: vii).

Bell and Shank (2007: 166) go on to argue that 'blended librarians are the hybrid library professionals of the future'. The blended librarianship movement is supported by a website hosting a dedicated portal and online community (Bell and Shanks, 2007) and the concept evidently resonates with practitioners across the globe working in diverse contexts. For instance, Bates (2007) describes 'the continuing evolution of the blended librarian at Southbank Institute of Technology' in Australia, while Donoghue (2007) uses the concept to describe the shift in her own role and those of her colleagues in the Virtual Learning Centre Team at Sheffield Hallam University in the UK. Sinclair (2009) applies the concept to transforming the reference desk in a learning commons at the University of North CarolinaAsheville and Cain et al. (2005) show how the skill set and team working promoted by Bell 
and Shank (2004) are not limited to support for learning and teaching, but can also can integrate and transform support for research and innovation through knowledge management at Ohio State University Medical Center.

\section{Differentiation of specialised technical roles}

The changing role of academic librarians in supporting learning and their professional development needs as teachers of information literacy are well documented (Albrecht and Baron, 2002; Biddiscombe, 2002; Peacock, 2001; Powis, 2004; Saunders, 2009; Walter, 2006). However, library support for research has moved up the agenda and is demanding more attention with the development of institutional repositories and the emergence of escience (or e-research) and virtual research environments alongside their equivalents in the learning and teaching arena (Brandt, 2007; Candela et al., 2009; Gold, 2007; Hey and Hey, 2006; Walters, 2007; Webb et al., 2007). The most challenging aspect here is the call for libraries to take on a substantial role in the management of both the outputs (e.g. electronic journal articles, conferences papers and academic theses) and the data (e.g. statistical, spatial or experimental data sets) from research projects: most commentators recognise that librarians have a part to play in facilitating access to data sets as an important element of the research knowledge base, but are less sure about exactly what role(s) they should have (e.g. data managers, data curators, data archivists) with serious concerns about the disciplinary knowledge requirements; however, there is general acknowledgement of the need for more education in data curation for various stakeholders (Gold, 2007; Swan and Brown, 2008; Pryor and Donnelly, 2009; Lewis, 2010).

Technology is a recurring theme in the discussion of changing roles and competencies in academic libraries, but writers generally differentiate between traditional jobs carried out in technology-rich environments and jobs involving new or significantly expanded responsibilities and skill sets (Choi and Rasmussen, 2009; Croneis and Henderson, 2002; Mathews and Pardue, 2009; Thompson, 2009). Thompson (2009: 31-32) defines electronic resources librarians, instructional design librarians and metadata cataloguers as 'Technology positions spun off from traditional library specialties', but sees digital collections librarians, Web librarians, GIS librarians and data research scientists as 'New technology specialist positions'. Choi and Rasmussen's (2009) analysis of specialist technology posts identifies four sub-groups concerned respectively with digital projects, digital services, digital collections and senior management. Thompson (2009: 101) also notes that the traditional role of systems librarian now covers a broader array of technologies and has evolved from the maintenance responsibilities of a 'support technician' to the development of 'unique solutions' as a systems operations manager and visionary library leader.

The literature reveals mixed views on whether a library or computer/IT background is better preparation for specialist technology posts in libraries, but the boundary-spanning nature of the role and the blending of technical, professional, managerial and interpersonal skills requirements are accepted dimensions. The broad skill set identified here is similar to trends evident in the information systems (IS) literature by some authors (Cortez et al., 2004; Mathews and Pardue, 2009). Choi and Rasmussen (2009) confirm the need for specialist technological skills in specialist jobs, but also found interpersonal, managerial and professional skills in high demand, consistent with their 2006 survey of digital library specialists, who reported a balanced set of technology, library and other skills requirements. Mathews and Pardue (2009: 257) identify significant overlap between the technology skill sets of librarians and IT professionals in their undifferentiated sample of 100 job ads and suggest that librarians 'continue to look more like IT professionals', confirming the trend 
towards merged library/IT roles (Woodsworth et al., 1992; Garrod, 1999; Norry, 2004). Goddard (2003) suggests a boundary-spanning solution to the library versus IS/IT question, advocating the combination of the standard MLS degree followed by a shorter IT diploma.

\section{Expansion of the information discipline}

The emergence of information science education programmes or tracks in the 1970s has been perceived by some as a competitive threat to librarianship (e.g. Grotzinger, 1986), but others welcomed 'a conscious attempt to introduce academic rigour and standardized research methodologies into an area which evolved on a largely ad hoc and pragmatic basis' (Martin, 1987: 130) or spotted an opportunity to elevate the discipline, by establishing an intellectual base that would unify practice and theory (Wilson and Hermanson, 1998). Commentators warned that boundaries were shifting and the diffuse nature of the emerging market for information workers would bring more significant competition from business schools and information systems programmes (Van House and Sutton, 1996; Crowley \& Brace, 1999), a threat that has not gone away (Bonnici et al., 2009).

Disciplinary identity has continued to be debated in the 21 st century, with the shift from library to information science now extending to information systems, information technology and computer science and the word 'library' often dropped from department/school names and programme portfolios (Cronin, 2002; Audunson et al., 2003; Um and Feather, 2007; Lynch, 2008; Bonnici et al., 2009). Audunson et al. (2003) and Um and Feather (2007) detect a more fundamental shift from a humanities and social sciences perspective to science and technology. Several authors note the move away from a library/institution-specific, professionally-oriented and service-based focus to a broader location-independent, academic and systems-based interest in all aspects of information (Audunson et al., 2003; Bonnici et al., 2009; Lynch, 2008). Audunson et al. (2003) see this as an undesirable departure from the inter/multi-disciplinary dynamic of a research-based professional field based on a blend of different subjects to the more limiting perspective of a pure academic discipline, where research is more concerned with refining theory than improving practice. Bonnici et al. (2009: 272) observes that 'the nature of the relationship of the $L$ [library] and $I$ [information] philosophies...remains unresolved'.

The formal establishment in 2005 of the iSchools Caucus, a select group of information schools deliberately positioning themselves apart from the mainstream library science tradition in a new 'iField', has refuelled earlier debates, with writers unsure what this move means for the future of professional education in our field (Bonnici et al., 2009; Cronin, 2005; Wallace, 2009). Members of the group have collectively and individually made bold claims about their intentions, prompting Cronin (2005: 363) to comment on the 'intelligent phrasing' of one School of Information's mission, but query whether the aspirations of others 'may be outpacing their assets'. Further examination of the phenomenon reveals that despite the widely publicised closure of formerly prominent MLS programmes, in practice the majority of the iSchools have continued to promote library education on their websites (Bonnici et al., 2009; Wallace, 2009), leading Bonnici et al. (2009: 273) to the reassuring conclusion that "The iField is not only "at the heart of everything", but has ingested the $L$ into its heart'.

Broady-Preston (2009) picks up the themes of identity and positioning in discussing the blurring and fusion of boundaries, both between the information and IT professions and within the library and information profession. She shows how this is formally acknowledged in the CILIP (2004: 2) Body of Professional Knowledge (used to accredit programmes in the 
UK), which identifies 'a degree of overlap with the knowledge bases of other professions, such as the British Computer Society, UK Council for Health Informatics Professionals and the Records Management Society', quoting the Chief Executive of The National Archives among others on the perceived silos and insularity of the library/information professions and the need to rethink traditional definitions of professional information work. Her survey of perspectives from experienced educators, senior practitioners and professional bodies reinforces the view of a discipline still searching for its identity in the classroom and on the playing field. Broady-Preston (2009: 275) concludes by citing two unique examples of UK programmes (the BA in Historical and Archival Studies at Aberystwyth and MSc in Chemoinformatics at Sheffield) that 'require not merely an inter-disciplinary approach, but a fusion of differing disciplines to create a new, composite area of study' and in effect a new breed of hybrid or blended information professional.

\section{Connections between academics and practitioners}

Library practitioners often complain about educators abandoning traditional subjects, such as cataloguing or book history (Quattrochi, 1999). Lynch (2008) confirms that there have been significant changes, with courses in cataloguing, book selection and reference work no longer part of the core curriculum; she also notes that the demotion of cataloguing has been hotly contested. However, information literacy now rivals cataloguing as the subject generating the strongest criticism from the practitioner community and revealing the most significant disconnect between the academy and the profession. Academic librarians frequently lament its absence or poor coverage in professional education and their inadequate preparation for teaching and other instructional activities, but this issue is rarely mentioned by professional educators (Peacock, 2001; Albrecht and Baron, 2002; Walter, 2006; Bewick and Corrall, 2010).

Although practitioners frequently claim that library educators are out of touch with the profession, many academics are keen to collaborate (notably through engaging practitioners as visiting lecturers/adjunct professors) and some education programmes are actually led and delivered by practitioners, typically via continuing/extended education departments (Heery, 1999; Johnson, 1997; Lynch, 2008). Heery (1999) describes the successful MSc established by UK practitioners in the south-west of England, while Lynch (2008) reports similar initiatives in the US. Audunson et al. (2003: 201) identify a need for short refresher or 'reeducation' courses for practising librarians and Lynch (2008) confirms growing interest in continuing professional education in her review, which is consistent with the move towards mandatory continuing professional development reported by Broady-Preston (2009).

Formal statements by professional and official bodies on the knowledge, skills or competencies that library and information practitioners are expected to demonstrate in professional roles can inform curriculum planning and indicate shared understandings between educators and practitioners on curriculum content; their usage by schools/departments also shows how the academy values formal accreditation and informal approbation by their professional constituency (Um and Feather, 2007; Lester and Van Fleet, 2008). However, the international networks and global markets that characterise the contemporary library and information field make reference to all relevant documents a daunting task, as educators arguably need to look beyond the accrediting and standard-setting organizations in their own countries to ensure that offerings meet wider expectations.

In the UK, for example, educators should refer to the Body of Professional Knowledge of the Chartered Institute of Library and Information Professionals (CILIP), the Subject Benchmark 
Statement for our discipline published by the Quality Assurance Association for Higher Education and the National Occupational Standards for our profession, issued by the relevant Sector Skills Council (CILIP, 2004; QAA, 2007; LLUK, 2008). In addition, they could consult the formal skills frameworks that have been developed for key employment sectors, such as the recently produced Government Knowledge and Information Management Professional Skills Framework (GKIMN, 2009) and the Information and Knowledge (IK) dimensions of the National Health Service Knowledge and Skills Framework (DH, 2004).

The government Professional Skills Framework is an interesting exemplar as it presents records managers, librarians, knowledge managers, information managers and others as a single unified Knowledge and Information Management (KIM) profession, exceeding the unification represented by merging the Library Association and Institute of Information Scientists into CILIP, which remains separate from the Records Management Society (CILIP, 2004; GKIMN, 2009). However, if concerned to reach international markets, UK educators would also need to consider the knowledge and competencies statements developed by relevant professional organisations around the world, such as the American Library Association's Core Competences of Librarianship (ALA, 2009), the Australian Library and Information Association's Core Knowledge Statement (ALIA, 2005), SLA's Competencies for Info Pros (Abels et al., 2003) and the International Federation of Library Associations Guidelines for Professional Library/Information Educational Programs (IFLA, 2003), as well as checking competencies and proficiencies for particular roles or specialist fields, such as reference/user services librarians (RUSA, 2003), instruction librarians (ACRL, 2008), technology specialists (Thompson, 2008) or health sciences librarians (MLA, 2007).

\section{Implications of trends and developments}

Our review has located the emergence of composite, hybrid and blended library and information professionals in the context of a converged, diffuse and expansive global information landscape. Hybridity and blending is evident in the strategies, structures, services, systems, spaces, skills and staff of academic libraries and related service departments in tertiary education. Key features of the contemporary landscape include overlapping roles, broad skillsets, stretched identities, specialised niches and competency gaps in strategic specialties. The academic side of the story, as reflected in the information and library schools and departments responsible for preparatory (and continuing) education, is similarly challenged in terms of its intellectual base, market standing, professional allegiances, stakeholder relationships and curricular treatment of practitioner priorities. Identity and status are issues for both academics and practitioners, but their concerns are different and there are also divergent perspectives within each constituency.

The current situation makes the design, development and delivery of library and information education problematic, creating tensions and dilemmas for curriculum planners tasked with meeting the needs of both their academic institutions and their professional communities. Figure 1 presents an analysis of the forces at play in the 'iField', showing the competing values surfaced in the academic and professional standpoints represented in the literature.

As we are working in a complex fast-moving pluralist context, traditional approaches to academic planning, with their long lead-in and gestation cycles, will not enable us to respond quickly and flexibly to stakeholder concerns and market demands. We must plan strategically, but using methods suited to dynamic environments, which support continual review and development of programmes and curricula, with reference to changing academic and professional needs and priorities, while also taking account of strategic moves within our 
parent institutions and key trends in the wider environment. Ackoff's (1981) concept of 'interactive planning' fits this context and the three principles that underpin his model meet the methodological criteria identified. His theory argues that strategic planning should be:

- participative - to build understanding and help implementation (for example, by engaging and interacting with stakeholders to develop strategies);

- continuous - to monitor the environment and evaluate changes (for example, by undertaking and acting on product and portfolio reviews);

- holistic - to co-ordinate and integrate multiple units and different levels (for example, by reviewing the whole portfolio, rather than planning selectively and separately).
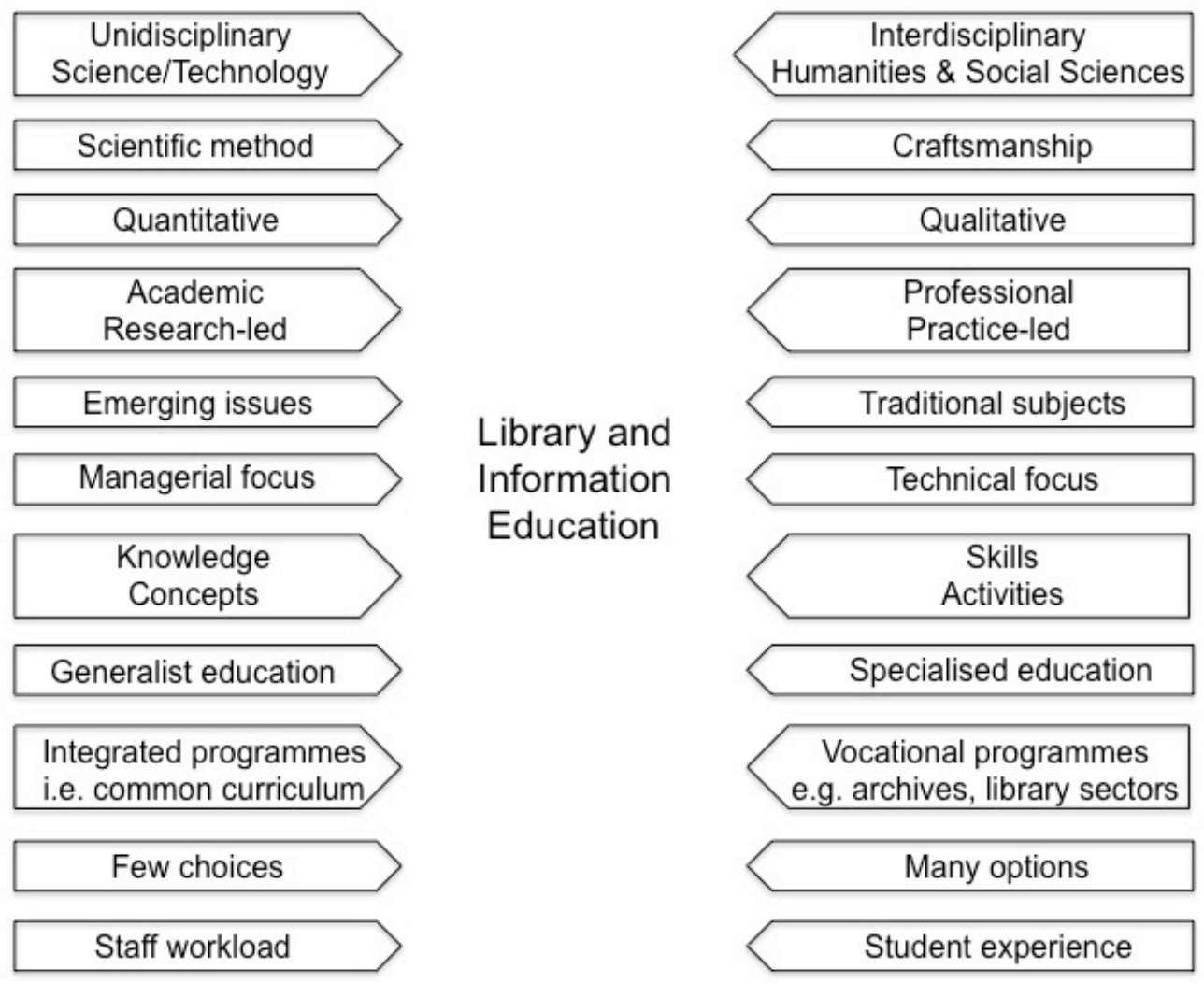

Figure 1. Force field analysis of information studies education

\section{Case study}

Case description

The Sheffield iSchool was founded in 1963 as the Postgraduate School of Librarianship. It has always had a strong research focus and later became the School of Librarianship and Information Science, then dropped librarianship from its title to become the Department of Information Studies. Sheffield was the first UK institution invited to join the iSchools group when membership was extended beyond North America in 2008/09 and then decided to adopt the name Information School as a clearer, simpler title for the international multicultural arena in which we now operate (with our formal title changing to School of Information).

Sheffield Information School has been awarded the top rating for the quality of its library and information science research in every national assessment to date, putting us in the number one position for 24 years. Our MA Librarianship is our flagship programme and leads the 
field with its distinctive combination of theory and practice, enabled by a policy of employing research-active staff with substantial practical experience and extensive professional networks, as well as involving visiting professors and leading practitioners in our teaching. We currently have around 20 academic staff, with additional teaching provided by our own Learning Technologist and the Academic Liaison Librarian for our discipline, who is formally contracted to work as a part-time teacher on our programmes.

Although originally set up as a postgraduate school, we now offer both postgraduate and undergraduate programmes that prepare candidates for the full spectrum of informationrelated careers, including specialist posts as librarians, information managers and information systems professionals, in addition to other roles where information handling is central or critical to the job. Our courses have diversified over time to include certificates, diplomas and undergraduate degrees, in addition to the traditional masters and $\mathrm{PhD}$, as well as specialised Masters (for hybrid information professionals) in Chemoinformatics, Health Informatics, Multilingual Information Management, Electronic \& Digital Library Management and Information Literacy. We also offer CPD pathways through our courses as 'professional enhancement' versions to complement our basic 'professional preparation' programmes, as well as individual modules for practitioners wanting to update their knowledge and skills. A key feature of our portfolio is the collaborative provision developed with other schools; for example, our MSc Information Systems is delivered with the Department of Computer Science and our MSc Information Systems Management with the Management School.

Our student numbers have expanded as our portfolio has diversified, so that we currently have around 350 taught students (around half of whom are postgraduates) and about 60 research students. Our largest intakes are in Information Management (BSc/BA and MSc) and Librarianship (MA), with the latter programme recruiting around 35 students per year. We attract students from all over the world, with approximately half our intake drawn from overseas, including large intakes from Asia and the Middle East. However the cultural mix varies between programmes: only a small proportion (c15\%) of undergraduates are from overseas, whereas there is a substantial majority of international students on both taught (c55\%) and research (c75\%) postgraduate programmes.

\section{Curriculum development as a continuous improvement strategy}

Changes in the environment and demands of the marketplace have necessitated continual review and renewal of the contents and delivery of our teaching portfolio, at both module and programme levels. The curriculum of established programmes has evolved to reflect research, innovation and developments in our field, dialogue with practitioners (including our Advisory Panel of senior information professionals) and feedback from students and employers. Over the years, we have added new topics and electives, implemented new methods of teaching and assessment, and experimented with new systems and technology (including course management systems and virtual classroom software for real-time delivery of distance education). We have also created new niche programmes in response to the emergence and growth of new professional specialisms matching our areas of expertise, which typically mix new purpose-designed units with modules from our existing portfolio.

Most changes have been incremental, but cumulatively amount to significant innovation. Many curriculum developments have been designed to prepare students for hybrid specialist roles, reflecting a longstanding interest in boundary-spanning information professionals shared by members of our Libraries \& Information Society and Educational Informatics research groups (Fowell and Levy, 1995; Corrall and Lester, 1996; Levy and Roberts, 2005; 
Cox, 2007; Corrall, 2008; Corrall and Cox, 2008). The current Sheffield model of hybrid information specialisms builds on earlier work that dates back to the time of the UK eLib programme (Corrall and Lester, 1996), which has evolved to reflect the complexity of the eresearch and Web 2.0 world (Corrall, 2008; Corrall and Cox, 2008). Figure 2 presents our current conception of the blended professional, differentiating three traditional specialist professional groups: library/information science specialists, IT/media specialists and academic/professional discipline specialists, labelled 'content', 'conduit' and 'context' specialists respectively; alternatively they can be seen as 'knowledge', 'infrastructure' and 'domain' specialists.

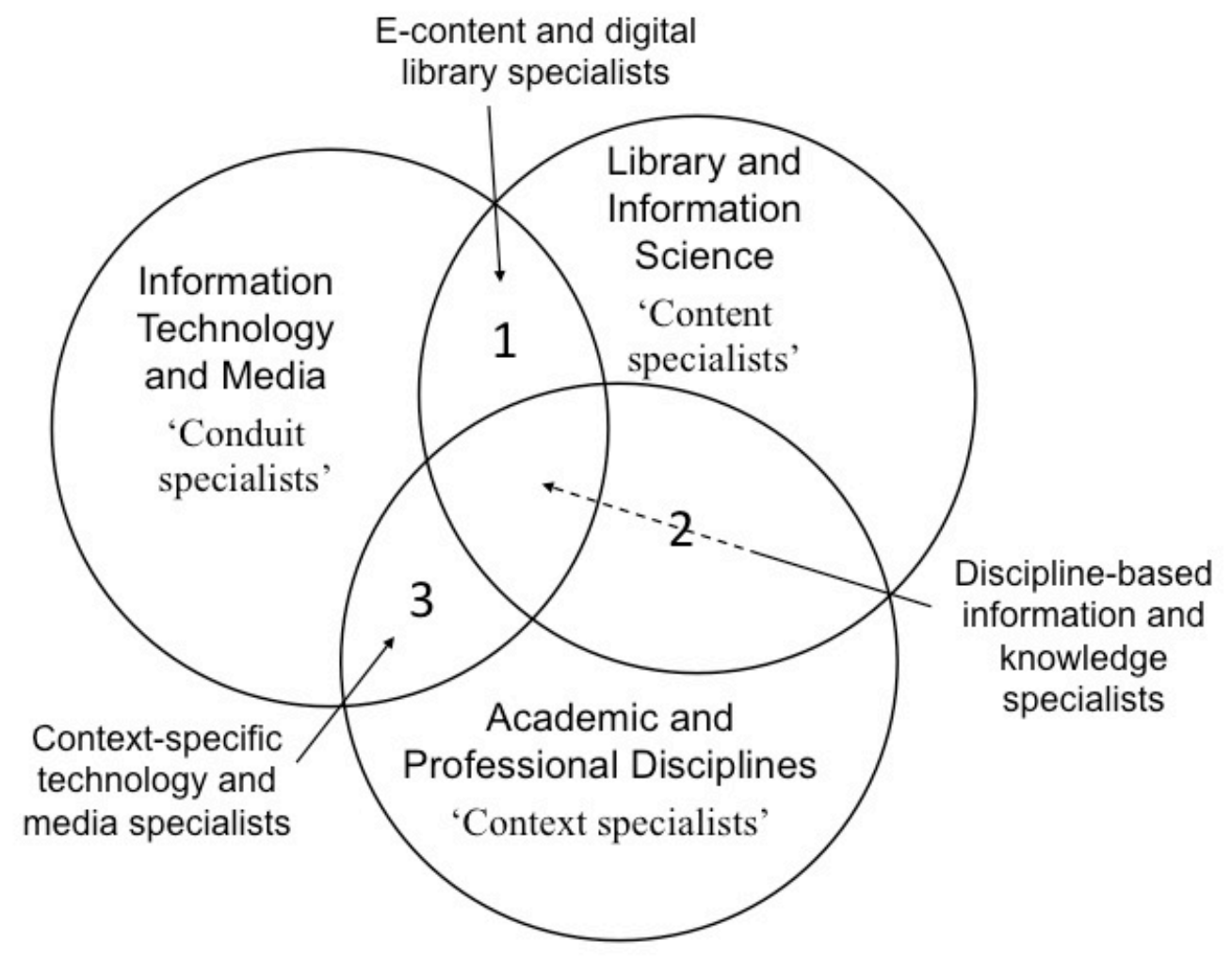

Figure 2. Sheffield model of blended information professionals

Within this model, we identify three broad categories of new hybrid specialists whose work spans the boundaries between the three established professional groups. These categories also include distinct sub-specialisms, illustrating how information professional roles have simultaneously become both cross-functional and more specialised, adding breadth and depth to an already specialised job. The following are examples of each category:

1. E-content and digital library specialists (content + conduit), e.g. electronic resources coordinators, digital collection project managers, directors of digital libraries, heads of estrategy, intranet/web managers and repository librarians;

2. Discipline-based information and knowledge specialists (content + context + conduit), e.g. subject/liaison librarians, information literacy co-ordinators, instructional design librarians, geographic information systems specialists, data librarians, data scientists;

3. Context-specific technology and media specialists (context + conduit), e.g. computerassisted learning specialists, educational/instructional/learning technologists. 


\section{Preparing and enhancing digital library managers}

The treatment of information technology in our postgraduate programmes has evolved in line with its integration into professional practice and everyday activities. Our Librarianship students are expected to be IT literate as a result of their undergraduate education and employment experience. However, we encourage them to take our non credit-bearing module on 'Essential Computing Skills', which provides hands-on practice in using advanced features of word-processing and presentation software, in addition to tuition on bibliographic management software, web authoring and website design, thus ensuring they have the skills required for other modules on their programme (and assumed by most employers). The ubiquity of IT in information work means that it is now a prominent feature of many of our modules, notably 'Information Retrieval: Search Engines and Digital Libraries' and 'Information Resources and Information Literacy', which are both core courses for Librarianship. Both modules have been continually reviewed and updated to incorporate the latest thinking on these subjects, which are important research areas for our world-leading Information Retrieval Research Group and Centre for Information Literacy Research.

Continuing advances and proliferation of both specialist systems and generic technologies in libraries (integrated library systems, electronic resource management systems, digital object/asset management systems, Web 2.0, etc.) have also prompted us to provide more extensive and explicit coverage of technology-related topics in other core modules taken by Librarianship students. For example, a few years ago we introduced a two-hour session on 'Managing information systems and technology' as part of our core course on 'Management for Library and Information Services' and recently added a second session on the topic to extend our coverage. Similarly, we have gradually built up our coverage of institutional repository management in our 'Academic and Research Libraries' module, which now includes an assessed group project over several weeks in which students investigate stakeholder attitudes to open access from the perspectives of academic researchers, library managers and journal publishers. One session associated with this module includes presentations from an acquisitions librarian, a commercial publisher and a serials agent, followed by discussions of alternative open access scenarios. Another session includes a case study from a senior practitioner at a university library that has had a leading role in institutional repository developments.

Students with an interest in the more technical aspects of electronic and digital library management can choose more specialist technology-related modules as elective units, for example 'Content Management Systems', 'Database Design', 'Educational Informatics', 'Human Computer Interaction and User Interface Design' or 'Information Storage and Retrieval Research'. The array of electives available to students at Sheffield reflects the breadth and diversity of our programme portfolio, which in turn reflects the wide-ranging interests and expertise of our staff, whose disciplinary backgrounds range from arts and humanities through to the pure and applied sciences, including several with computer science backgrounds and IT industry experience. Librarianship students can exploit our multidisciplinary strengths by taking modules designed primarily for Information Management or Information Systems students to focus their more specialised secondsemester studies on specific technology-related subjects. They can also choose a technologyrelated topic for their dissertation project: subjects recently researched by Librarianship students include virtual reference services, next-generation OPACs, institutional repositories, RFID technology, digital video archives and image retrieval. Studying in an iSchool with a broadly-based portfolio can thus offer librarianship students interested in a digital library career the possibility of following a tailored technology pathway. 
In addition to the electives already mentioned, in 2009 we launched a new unit on 'Digital Multimedia Libraries' specifically aimed at students interested in working at the contentconduit intersection of our blended professional model (shown in Figure 2). This module gives students hands-on experience of building a digital library as part of their assessed coursework and also includes a visit to a university library with a large digital library development team and presentations from specialist practitioners in the field. Our final innovation in digital library education is our new MSc in Electronic \& Digital Library Management, which incorporates the module just described, as well as another new module on 'Management and Strategy for Electronic and Digital Libraries', supplemented by core units on 'Designing Usable Websites' and 'Information Retrieval'. Students can take 'Academic and Research Libraries' as a sector-specific elective along with other electives, such as those listed earlier. We also offer a more flexible mixed-mode part-time PGCert in Electronic \& Digital Library Management, delivered via two one-week residential blocks and a supervised work-based project, intended for mid-career professionals seeking to refresh and upgrade their skills to meet emergent job opportunities.

\section{Preparing and enhancing information literacy educators}

The treatment of information literacy in our postgraduate portfolio is a good example of how a subject flagged by practitioners has progressively gained ascendancy within an existing core module and encouraged a shift in focus, in addition to stimulating curriculum innovation in a novel specialist elective and a whole specialised programme. A module on information resources has been central to our Librarianship programme for many years, but has evolved in line with the changing digital information landscape and the impact of the network revolution on library resources and services. In 2005, we changed the module name from 'Access to Information Resources' to 'Information Resources and Information Literacy', signalling an increased emphasis on the latter in the syllabus. We also started to change the emphasis in other ways, aware of criticisms from practitioners and graduates about not providing adequate preparation for their roles as information skills trainers and information literacy educators.

The focus of this module was previously on enabling students to understand the concept of information literacy and to develop their own competence, rather than on developing their abilities as information literacy teachers, though we highlighted the teaching/training role by including case studies presented by practitioners. However, in 2006 we introduced a new 'search/teach task', in which students work in pairs over four weeks to create a short instructional guide to using a specific aspect of a particular database (Emerald Insight, Google Scholar, Library and Information Science Abstracts or Web of Knowledge). As preparation for this task, we introduce them to theories about learning styles and principles of learning design, as well as providing guidelines on designing user documentation. In addition to their database guide, students also have to produce a list of links to other recommended guides, tutorials, evaluations and sources of information about their allocated database and publish this using a Web 2.0 tool. The final part of the task involves evaluating one of the guides produced by their classmates.

This unassessed assignment has succeeded in making students more confident about applying for professional roles that involve training or teaching and has also prepared them better for job interviews, as candidates for entry-level posts in UK academic libraries are often asked to design and deliver a short information skills session as part of the selection process. However, in 2009, in response to employer and student feedback, we extended our coverage 
of information literacy teaching further, by adding an optional 'practitioners' seminar' to the module, enabling students to work together on the development of their teaching skills in a half-day workshop session, run twice and led by two expert practitioners, who are both National Teaching Fellows, as well as being Fellows of CILIP and authors of one of the leading texts on information literacy teaching (Webb and Powis, 2004).

In addition to developing the content of this core module, in 2005, we launched a new seminar-based elective on 'Information Literacy Research', which aims to deepen understanding of key research problems in information literacy and appropriate methods of investigating them, involving researchers in the field and covering both theoretical and practical perspectives. Our final innovation in information literacy education is our new MA in Information Literacy, which incorporates the two modules already described and the 'Educational Informatics' module mentioned above, as well as a new double-length module, 'Education for Information Literacy', which provides more in-depth treatment and critical understanding of information literacy pedagogies through reflective practice. Designated units from this new programme can also be combined to obtain Certificate or Diploma awards or taken as individual modules, for example by experienced practitioners wanting to update and/or enhance knowledge and skills gained in their initial professional education.

\section{Curriculum review as a holistic planning activity}

In 2008-09 we initiated a more fundamental review of our postgraduate taught programmes, in an effort to streamline delivery, simplify offerings, facilitate access for work-based learners and in particular to meet the needs of practitioners in emergent specialist roles (including blended librarians). The review was triggered by operational problems, including difficulties in resourcing and scheduling our growing portfolio of modules to enable all the combinations that our programme regulations allowed, but it was quickly recognised as a strategic priority to facilitate continuing development and renewal of our educational provision. We have drawn on an array of data sources to inform our work, including meetings with the Vice-Chancellor and our Advisory Panel, a study tour to North America by a former head of department, focus groups with current students and a panel session on the future of professional education at the 2009 CILIP Umbrella conference. Figure 3 shows the conceptual model for a revised streamlined curriculum as the output from the first stage.

The model proposes a simplified programme structure, based on shared core modules common to all programmes throughout semester 1 , followed by a combination of shared and parallel core modules in the early part of semester 2, after which students begin to specialise in their chosen fields by taking an identified specialist seminar stream, leading to the completion of a dissertation on a chosen topic. It was intended to improve economies of scale, assist selection of courses by students and facilitate development of new programmes for emergent markets. It represents a significant departure from the present situation: all our current programmes meet the core knowledge requirements for CILIP accreditation, but they do this through different configurations of shared and separate modules. However, a unified structure with a common core is consistent with trends towards convergence in our sector.

The next stage involved comparing the topics covered by our current core modules with a view to rationalisation and resulted in a proposed four-part core curriculum for semester 1 , suggesting the merger or convergence of two pairs of modules. However, moving from the concept to a concrete plan proved problematic, with several stakeholders arguing that it was essential for recognised professional groups (such as librarians and information systems professionals), to develop a professional ethos and distinct identity from the start of their 
programmes and that the subjects in question needed to be presented and discussed in a meaningful operational context; suggesting that if we combined the modules, we might need separate streams for some topics or activities. A related proposal from this phase was to use the same four-part structure to group elective modules in semester 2, on the basis that this would help students to consider whether they wanted to focus their semester 2 studies by specialising in one particular area (knowledge organisation, information literacy, organisation behaviour or social context) or choose modules from different groups to gain a more broadlybased generalist education. At present students typically have to choose two or three electives from a diverse list of 15-20 modules and often find this a challenging task.

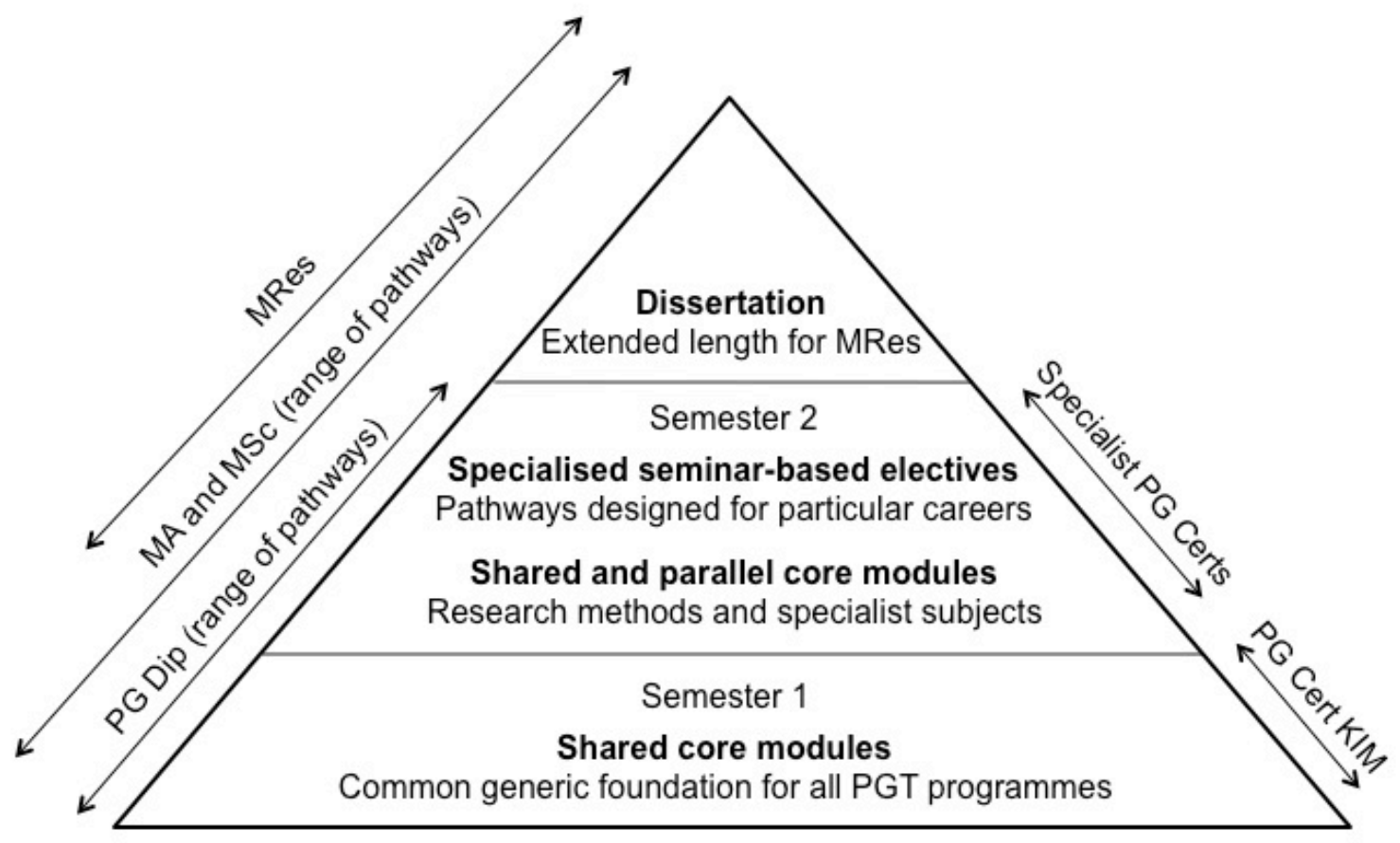

Figure 3. Conceptual model of new programme structure

Work on the review is continuing and initial results are promising. The conceptual framework has evolved from the original common core of four modules to a common core of four subject areas, but with ongoing discussions on the scope for interactions between different modules in the same subject area. Some innovative proposals for engaging the Librarianship and Information Systems students in joint activities on information society themes have already emerged, along with ideas for significantly extending coverage of both traditional (e.g. cataloguing) and contemporary knowledge organisation systems in our 'Information Retrieval' module. We are also extending the grouping of semester 2 electives beyond the four core subjects as our range of modules offers numerous other potentially useful configurations, including suites of modules that could form specialised pathways for blended academic librarians, for both initial and continuing professional education.

\section{Education for blended librarianship}

Table 1 [appended] shows the MA Librarianship core curriculum mapped against the QAA (2007) Subject Benchmark statement and the Sheffield iSchool four core subjects. Table 2 [appended] shows generalist and specialised pathways through the programme for academic librarians, identifying clusters of modules for students interested in careers as Information Literacy Educators and Digital Library Managers, in addition to displaying other modules 
currently on offer, which can be chosen in any combination to support a variety of career options.

As already indicated, continuing professional development provision for blended librarians ranges from individual modules to Certificate, Diploma and Masters programmes in Information Literacy, Electronic \& Digital Library Management, and Health Informatics. For example, practitioners who graduated from programmes offering only basic coverage of information literacy can take any of the specialist modules listed as individual units or take the PGCert in Information Literacy, including modules on Education for Information Literacy, Educational Informatics and Information Literacy Research. The next phase of the review will explore new modes and styles of delivery, such as using different blends of faceto-face and online teaching and learning; changing the balance between lectures and seminars, with more practitioner masterclasses; and moving from delivery via 10-12 weekly two- or three-hour sessions to full-day sessions over a shorter period or one-week blocks.

\section{Conclusion}

Library education has been a contentious issue for several decades. The problems identified are not easily resolved as there are complex forces at work, multiple constituencies to satisfy and competing values to reconcile. However, commentators tend to polarise the debate and present a dichotomy that is not borne out in practice. Experience at Sheffield has shown that it is possible for librarianship education not only to survive, but also to thrive in an academic research-led iSchool with an international reputation in information science. We see no inconsistency in maintaining a strong professional focus, informed by best practice in the field, while also attaining high academic standards, inspired by leading-edge research.

Our case argues that multidisciplinary strengths and research excellence can be blended with professional expertise and educational creativity to provide top-quality programmes for both specialist library and information professionals and others for whom information is not the basis of their professional identity. Indeed, the blurring of boundaries between professions and the growth in hybrid and blended information-based roles strengthens the case for a unified and integrated approach to information education, as preparation for working in the complex pluralist information environments awaiting our graduates.

Even so, the complexity of both the information landscape and the organisational arena demand both breadth and depth in skills and knowledge for jobs that require cross-functional and highly-specialised competencies, which means that candidates need to have the option of taking modules that will provide a broadly-based foundation and tailored preparation for specialised roles in fields such as information literacy education, digital library management and data curation, as distinctive specialties. As the pace of change shows no sign of slowing down, the need for CPD will increase, particularly for blended professionals, whose updating needs are clearly greater than those of traditional professionals. Flexible delivery of continuing professional education and continuing dialogue between educators and practitioners will be critically important here, as will further research into the roles, skills and professional identities of these key players in the academic library of the future.

\section{Acknowledgement}

Paper presented at Academic Librarian 2: Singing in the Rain, Conference towards Future Possibilities, 11-12 March 2010, Hong Kong 


\section{References}

Abbott, A.D. (1998), "Professionalism and the future of librarianship", Library Trends, Vol. 46 No. 3, pp. 430-443.

Abels, E., Jones, R., Latham, J., Magnoni, D. and Marshall, J.G. (2003), Competencies for Information Professionals of the 21st Century, Rev. ed., Special Libraries Association, Alexandria VA, available at: http://www.sla.org/PDFs/Competencies2003 revised.pdf (accessed 11 April 2010).

Ackoff, R.L. (1981), Creating the Corporate Future: Plan or Be Planned For, John Wiley, Chichester.

ACRL (2008), Association of College and Research Libraries, Standards for Proficiencies for Instruction Librarians and Coordinators, American Library Association, Chicago, IL, available at: http://www.ala.org/ala/mgrps/divs/acrl/standards/profstandards.pdf (accessed 11 April 2010).

ALA (2009), ALA's Core Competences of Librarianship, Final version, American Library Association, Chicago, IL, available at: http://www.ala.org/ala/educationcareers/careers/corecomp/corecompetences/index.cf m (accessed 11 April 2010).

Albrecht, R. and Baron, S. (2002), "The politics of pedagogy: expectations and reality for information literacy in librarianship", Journal of Library Administration, Vol. 36, No. 1-2, pp. 71-96.

ALIA (2005), The Library and Information Sector: Core Knowledge, Skills and Attributes. Rev. ed., Australian Library and Information Association, Canberra, available at: http://www.alia.org.au/policies/core.knowledge.html (accessed 11 April 2010).

Allen, D.K. and Wilson, T.D. (1996), "Information strategies in UK higher education institutions", International Journal of Information Management, Vol. 16 No. 4, pp. 239-251.

Allen, L. (2005), "Hybrid Librarians in the 21st Century Library: A Collaborative ServiceStaffing Model", in 12th National Conference, Association of College \& Research Libraries, April 7-10, 2005, Minneapolis, Minnesota, ACRL, Washington, DC, pp. 291-301, available at: http://www.acrl.org/ala/mgrps/divs/acrl/events/pdf/allen05.pdf (accessed 11 April 2010).

Audunson, R., Nordlie, R. and Spangen, I.C. (2003), "The complete librarian - an outdated species? LIS between profession and disciplne", New Library World, Vol. 104 No. 6, pp. 195-202.

Bates. V. (2007), "Systems and synapses", paper presented at Information Online 2007: 13th Exhibition \& Conference, 30th January-1st February 2007, Sydney, Australian Library and Information Association, Canberra, available at: http://conferences.alia.org.au/online2007/Presentations/31Jan.B9.systems.and.synapse s.pdf (accessed 11 April 2010).

Beagle, D. (1999), "Conceptualizing the information commons", Journal of Academic Librarianship, Vol. 25 No. 2, pp. 82-89.

Beatty, S. and White, P. (2005), "Information commons: models for eLiteracy and the integration of learning", Journal of eLiteracy, Vol. 2 No. 1, pp. 2-14, available at: http://www.jelit.org/52/01/JeLit_Paper_16.pdf (accessed 11 April 2010).

Bell, S.J. and Shank, J.D. (2004), "The blended librarian: a blueprint for redefining the teaching and learning role of academic librarians", College \& Research Libraries News, Vol. 65 No. 7, pp. 372-375, available at:

http://www.ala.org/ala/mgrps/divs/acrl/publications/crlnews/2004/jul/blendedlibrarian .cfm (accessed 11 April 2010). 
Bell, S.J. and Shank, J.D. (2007), Academic Librarianship by Design: A Blended Librarian's Guide to the Tools and Techniques, American Library Association, Chicago, IL.

Bernbom, G. (1998) "Institution wide information strategies: a CNI initiative", Information Technology and Libraries, Vol. 17 No. 2, pp. 87-92.

Bewick, L. and Corrall, S. (2010), "Developing librarians as teachers: a study of their pedagogical knowledge", Journal of Librarianship and Information Science, Vol. 42 No. 2, pp. 97-110.

Biddiscombe, R. (2002), "Learning support professionals: the changing role of subject specialists in UK academic libraries", Program, Vol. 36 No. 4, pp. 228-235.

Bonnici, L.J., Subramaniam, M.M. and Burnett, K. (2009), "Everything old is new again: the evolution of library and information science education from LIS to iField", Journal of Education for Library and Information Science, Vol. 50 No. 4, pp. 263-274.

Brandt, D.S. (2007), "Librarians as partners in e-research: Purdue University Libraries promote collaboration", College \& Research Libraries News, Vol. 68 No. 6, pp. 3657, 396, available at:

http://www.ala.org/ala/mgrps/divs/acrl/publications/crlnews/2007/jun/partnerseresear ch.cfm (accessed 11 April 2010).

Breaks, M. (1991), "Information systems strategies", British Journal of Academic Librarianship, Vol. 6 No. 2, pp. 65-70.

Broady-Preston, J. (2009), "Professional education, development and training in a Web 20.0 environment: a case study of the UK", New Library World, Vol. 110 No. 5/6, pp. 265279.

Cain, T.J., Rodman, R.L., Sanfilippo, F. and Kroll, S.M. (2005), "Managing knowledge and technology to foster innovation at The Ohio State University Medical Center", Academic Medicine, Vol. 80 No. 11, pp. 1026-1031.

Candela, L., Castelli, D. and Pagano, P. (2009), 'On-demand virtual research environments and the changing roles of librarians", Library Hi Tech, Vol. 27 No. 2, pp. 239-251.

Choi, Y. and Rasmussen, E. (2006), "What Is needed to educate future digital librarians: a study of current practice and staffing patterns in academic and research libraries", $D$ Lib Magazine, Vol. 12 No. 9, available at: http://www.dlib.org/dlib/september06/choi/09choi.html (accessed 11 April 2010).

Choi, Y. and Rasmussen, E. (2009), "What qualifications and skills are important for digital librarian positions in academic libraries? A job advertisement analysis", Journal of Academic Librarianship, Vol. 35 No. 5, pp. 457-467.

CILIP (2004), Body of Professional Knowledge, Chartered Institute of Library and Information Professionals London, available at: http://www.cilip.org.uk/sitecollectiondocuments/PDFs/qualificationschartership/BPK. pdf (accessed 11 April 2010).

Cimbala, D. (1987), "The scholarly information center: an organizational model", College \& Research Libraries, Vol. 48 No. 5, pp. 393-398.

Corrall, S. (2008), "The emergence of hybrid professionals: new skills, roles and career options for the information professional", in: Turner, C. (Ed.), Online Information 2008 Proceedings, Incisive Media, London, pp.67-73.

Corrall, S. and Cox, A. (2008), "Capturing the hybrid ground", Library + Information Update, Vol. 7 No. 7-8, pp. 42-44.

Corrall, S. and Lester, R. (1996), "Professors and professionals: on changing boundaries", in Cuthbert, R. (Ed.), Working in Higher Education, Society for Research into Higher Education \& Open University Press, Buckingham, pp.84-100. 
Cortez, E.M., Dutta, S.K. and Kazlauskas, E.J. (2004), "What the library and information professional can learn from the information technology and project management areas", Portal: Libraries and the Academy, Vol. 4 No. 1, pp. 131-144.

Cox, A. (2007), "The power and vulnerability of the "new professional": web management in UK universities", Program, Vol. 41 No. 2, pp. 148-169.

Creth, S, and Lowry, C.B. (1994), "The Information Arcade: playground for the mind", Journal of Academic Librarianship, Vol. 20 No. 1, pp. 22-23.

Crockett, C., McDaniel, S. and Remy, M. (2002), "Integrating services in the information commons: toward a holistic library and computing environment", Library Administration \& Management, Vol. 16 No. 4, pp. 181-186.

Croneis, K.S. and Henderson, P. (2002), "Electronic and digital library positions: a content analysis of announcements from 1990 through 2000", Journal of Academic Librarianship, Vol. 28 No. 4, pp. 232-237.

Cronin, B. (2002), "Holding the center while prospecting at the periphery: domain identity and coherence in North American information studies education", Education for Information, Vol. 20 No. 1, pp. 3-10.

Cronin, B. (2005), "An I-dentity crisis? The information schools movement", International Journal of Information Management, Vol. 25 No. 4, pp. 363-365.

Crowley, B. and Brace, B. (1999), "A choice of futures: is it libraries versus information?", American Libraries, Vol. 30 No. 4), pp. 76-77, 79.

DH (2004), The NHS Knowledge and Skills Framework (NHS KSF) and the Development Review Process, Department of Health, Agenda for Change Project Team, Leeds, available at:

http://www.dh.gov.uk/dr_consum_dh/groups/dh_digitalassets/@dh/@en/documents/d igitalasset/dh 4090861.pdf (accessed 11 April 2010).

Donoghue, A. (2007), "The blended librarian's approach to supporting staff with e-learning", SCONUL Focus, No. 40, pp. 30-32, available at:

http://www.sconul.ac.uk/publications/newsletter/40/10.pdf (accessed 11 April 2010).

Earl, M.J. (1989), Management Strategies for Information Technology, Prentice Hall, New York, NY.

Earl, M.J. \& Skyrme, D.J. (1992), “Hybrid managers: what do we know about them?", Journal of Information Systems, Vol. 1 No. 2, pp. 169-187.

Ferguson, C (2000), "Shaking the conceptual foundations, too: integrating research and technology support for the next generation of information service", College \& Research Libraries, Vol. 61 No. 4, pp. 300-311.

Field, C. (2001), "Theory and practice: reflections on convergence in United Kingdom universities", Liber Quarterly, Vol. 11 No. 3, pp. 267-289, available at: http://webdoc.gwdg.de/edoc/aw/liber/lq-3-01/10field.pdf (accessed 11 April 2010).

Fowell, S. and Levy, P. (1995), "Developing a new professional practice: a model for networked learner support in higher education”, Journal of Documentation, Vol. 51 No. 3, pp. 271-280.

Garrod, P. (1999), "Survival Strategies in the Learning Age: Hybrid Staff and Hybrid Libraries", Aslib Proceedings, Vol. 51 No. 6, pp.187-194.

GKIMN (2009), Government Knowledge and Information Management Professional Skills Framework, The National Archives, Government Knowledge and Information Management Network, London, available at:

http://gkimn.nationalarchives.gov.uk/documents/government-kim-skills-frameworkfinal.pdf (accessed 11 April 2010).

Goddard, L. (2003), "The integrated librarian: IT in the systems office", Library Hi Tech, Vol. 21 No. 3, pp. 280-288. 
Gold, A. (2007), "Cyberinfrastructure, data, and libraries, part 2: Libraries and the data challenge: roles and actions for libraries", D-Lib Magazine, Vol. 13 No. 9/10, available at: http://www.dlib.org/dlib/september07/gold/09gold-pt2.html (accessed 11 April 2010).

Grotzinger, L.A. (1986), “Curriculum and teaching styles: evolution of pedagogical patterns”, Library Trends, Vol. 34 No. 3, pp. 451-468.

Hanson, T. (Ed.) (2005), Managing Academic Support Services in Universities: The Convergence Experience, Facet, London.

Heery, M. (1999), "Practitioners as educators: the Bristol MSc in Information and Library Management”, Library Management, Vol. 48 No. 3, pp. 120-130.

Hey, T. and Hey, J. (2006), "e-Science and its implications for the library community", Library Hi Tech, Vol. 24 No. 4, pp. 515-528.

Hirshon, A. (1998), Integrating Computing and Library Services, CAUSE Professional Paper Series, 18, CAUSE, Boulder, CO.

Hoggan, D.B. (2003), "Faculty status for librarians in higher education", Portal: Libraries and the Academy, Vol. 3 No. 3, pp. 431-445.

Hughes, A. (1997), "Information strategy - threat or opportunity?", Librarian Career Development, Vol. 5 No. 2, pp. 60-66.

IFLA (2003), Guidelines for Professional Library/Information Educational Programs, 3rd rev. draft, International Federation of Library Associations and Institutions, Education and Training Section, The Hague, available at: http://archive.ifla.org/VII/s23/bulletin/guidelines.htm (accessed 11 April 2010).

JFC (1993), John Fielden Consultancy, Supporting Expansion: A Report on Human Resource Management in Academic Libraries, for the Joint Funding Councils' Libraries Review Group, HEFCE, Bristol, available at: http://www.hefce.ac.uk/Pubs/HEFCE/1994/m3 93.htm (accessed 11 April 2010).

Johnson, I.M. (1997), "Peering into the mist and struggling through it - the education and training of the future information professional", Journal of Librarianship and Information Science, Vol. 29 No. 3, pp. 3-7.

Law, D. (2009), “An awfully big adventure: Strathclyde's digital library plan”, Ariadne, No. 58, available at: http://www.ariadne.ac.uk/issue58/law/ (accessed 11 April 2010).

Lewis, M. (2010), 'Libraries and the management of research data", in McKnight, S. (Ed.), Envisioning Future Academic Library Services: Initiatives, Ideas and Challenges, Facet, London, pp. 145-168.

Levy, P. (2008), "Foreword", in Ford, N. Web-Based Learning through Educational Informatics: Information Science Meets Educational Computing, Information Science Publishing, HersHey, PA, pp. vii-viii.

Levy, P. and Roberts, S. (Eds) (2005), Developing the New Learning Environment: The Changing Role of the Academic Librarian, Facet, London.

Levy, P., Ford, N., Foster, J., Madden, A., Miller, D., Nunes, M.B., McPherson, M. and Webber, S. (2003), "Educational informatics: an emerging research agenda", Journal of Information Science, Vol. 29 No. 4, pp. 298-310.

LLUK (2008), Information and Library Services, Archives Services and Records Management, National Occupational Standards, Lifelong Learning UK, London, available at: http://www.lluk.org/documents/nos-information-library-servicesarchives-and-record-managment-full-suite.pdf (accessed 11 April 2010).

Lynch, B.P. (2008), "Library education: its past, its present, its future", Library Trends, Vol. 56 No. 4, pp. 931-953.

Martin, W.J. (1987), "From library studies to information science", Education for Information, Vol. 5 No. 2-3, pp. 129-137. 
Mathews, J.M. and Pardue, H. (2009), "The presence of IT skill sets in librarian position announcements", College \& Research Libraries, Vol. 70 No. 3, pp. 250-257.

McKnight, S. (2002), "Managing cultural change: the challenge of merging library services, curriculum development and academic professional development", IFLA Journal, Vol. 28 No. 5/6, pp. 266-272, available at: http://archive.ifla.org/V/iflaj/art280506.pdf (accessed 11 April 2010).

Michalko, J. (2000), "Equilibrium and opportunism: information strategies and the new environment", New Library World, Vol. 101 No. 1, pp. 6-12.

MLA (2007), Competencies for Lifelong Learning and Professional Success: The Educational Policy Statement of the Medical Library Association, Medical Library Association, Chicago, IL, available at: http://www.mlanet.org/education/policy/ (accessed 11 April 2010).

Norry, J. (2004), "The changing staff experience", in Oyston, E. (Ed.), Centred on Learning: Academic Case Studies in Learning Centre Development, Gower, Aldershot, pp. 5795.

Oyston, E. (Ed.) (2004), Centred on Learning: Academic Case Studies in Learning Centre Development, Gower, Aldershot.

Peacock, J. (2001), "Teaching skills for teaching librarians: postcards from the edge of the educational paradigm", Australian Academic \& Research Libraries, Vol. 32 No. 1, pp. 26-42, available at: http://alia.org.au/publishing/aarl/32.1/full.text/jpeacock.html (accessed 11 April 2010).

Powis, C. (2004), "Developing the academic librarian as learning facilitator", in Oldroyd, M. (Ed.), Developing Academic Library Staff for Future Success, Facet, London, pp. 8393.

Pryor, G. and Donnelly, M. (2009), "Skilling up to do data: whose role, whose responsibility, whose career?”, International Journal of Digital Curation, Vol. 2 No. 4, pp. 158-170, available at: http://www.ijdc.net/index.php/ijdc/article/view/126 (accessed 11 April 2010).

QAA (2007) Librarianship and Information Management, Subject Benchmark Statement, QAA 201 12/07. Gloucester: Quality Assurance Agency for Higher Education, available at:

http://www.qaa.ac.uk/academicinfrastructure/benchmark/statements/Librarianship07. pdf (accessed 11 April 2010).

Quattrochi, E. (1999) 'An outsider's thoughts on the education of librarians', American Libraries, 30 (4), 82-85.

RUSA (2003) Task Force on Professional Competencies. Professional Competencies for Reference and User Services Librarians, American Library Association, Reference and User Services Association, Chicago, IL, available at: http://www.ala.org/ala/mgrps/divs/rusa/resources/guidelines/professional.cfm (accessed 11 April 2010).

Rusbridge, C. (1998) 'Towards the hybrid library', D-Lib Magazine, Vol. 4 No. 7/8, available at: http://www.dlib.org/dlib/july98/rusbridge/07rusbridge.html (accessed 11 April 2010).

Saunders, L. (2009), "The future of information literacy in academic libraries: a Delphi study", Portal: Libraries and the Academy, Vol. 9 No. 1, pp. 99-114. 
Sayers, R. (2001), “Open relationships, de-facto marriages, or shotgun weddings?: the convergence and integration of libraries and computing/information technology services within Australian universities", Australian Library Journal, Vol. 50 No. 1, pp. 53-71, available at:

http://archive.alia.org.au/alj/50.1/full.text/open.relationships.html (accessed 11 April 2010).

Sidgreaves, I. (1989), “The electronic campus - an information strategy: organizational issues", in Brindley, L.J. (Ed.), The Electronic Campus: An Information Strategy, British Library Board, London, pp. 65-80.

Sinclair, B. (2009), "The blended librarian in the learning commons: new skills for the blended library", College \& Research Libraries News, Vol. 70 No. 9, pp. 504-507, 516, available at: http://www.ala.org/ala/mgrps/divs/acrl/publications/crlnews/2009/oct/blended librari an.cfm (accessed 11 April 2010).

Sitter, C., Matthis, D., Petersen, L. and Sherif, S. (Eds) (2009), "Overview”, Alaska School Library Handbook. Alaska Department of Education and Early Development, Juneau, available at: http://aklibraryhandbook.pbworks.com/Overview (accessed 11 April 2010).

Sutherland, P. (1992), The Management of Integrated Learning Resources, Council of Polytechnic Librarians, Brighton.

Swan, A. and Brown, S. (2008), The Skills, Role and Career Structure of Data Scientists and Curators: An Assessment of Current Practice and Future Needs, Report to the JISC, Key Perspectives, Truro, available at: http://www.jisc.ac.uk/publications/documents/dataskillscareersfinalreport.aspx (accessed 11 April 2010).

Thompson, S.M. (Ed.) (2008), Core Technology Competencies for Librarians and Library Staff: A LITA Guide, Neal-Schuman, New York, NY.

Um, A.Y. and Feather, J. (2007), "Education for information professionals in the UK", International Information \& Library Review, Vol. 39 No. 3-4, pp. 260-268.

Van House, N. and Sutton, S.A. (1996), "The panda syndrome: an ecology of LIS education", Journal of Education for Library and Information Science, Vol. 37 No. 2, pp. 131147.

Wallace, D.P. (2009), "The iSchools, education for librarianship, and the voice of doom and gloom", Journal of Academic Librarianship, Vol. 35 No. 5, pp. 405-409.

Walter, S. (2006), "Instructional improvement: building capacity for the professional development of librarians as teachers", Reference and User Services Quarterly, Vol. 45 No. 3, pp. 213-218.

Walter, S. (2008), "Librarians as teachers: a qualitative inquiry into professional identity", College \& Research Libraries, Vol. 69 No. 1, pp. 51-71.

Walters, T.O. (2007), "Reinventing the library - how repositories are causing librarians to rethink their professional roles", Portal: Libraries and the Academy, Vol. 7 No. 2, pp. 213-225.

Webb, J. and Powis, C. (2004), Teaching Information Skills: Theory and Practice, Facet, London.

Webb, J., Gannon-Leary, P. \& Bent, M. (2007), Providing Effective Library Services for Research, Facet, London.

Whitchurch, C. (2008), "Shifting identities and blurring boundaries: the emergence of third space professionals in UK higher education", Higher Education Quarterly, Vol. 62 No. 4, pp. 377-396. 
Whitchurch, C. (2009), "The rise of the blended professional in higher education: a comparison between the United Kingdom, Australia and the United States", Higher Education, Vol. 58 No. 3, pp. 407-418.

White, H.S. (2003), “The successful future of the librarian: bookman or knowledge worker?", Australian Academic \& Research Libraries, Vol. 34 No. 1, pp. 1-13, available at: http://alia.org.au/publishing/aarl/34.1/full.text/white.html (accessed 11 April 2010).

Wilson, A.M. and Hermanson, R. (1998), "Educating and training library practitioners: a comparative history with trends and recommendations", Library Trends, Vol. 46 No. 3, pp. 467-504.

Woodsworth, A., Maylone, T. and Sywak, M. (1992), "The Information job family: results of an exploratory study", Library Trends, Vol. 41 No. 2, pp. 250-268.

\section{Biographical note}

Sheila Corrall is Professor of Librarianship \& Information Management and Head of the Information School at the University of Sheffield. Her previous positions have included Director of Academic Services at the University of Southampton, University Librarian of the University of Reading and Head of Information Services at the Science Reference and Information Service of the British Library. She is currently Chair of the British Association for Information and Library Education and Research (BAILER) and was the first President of the Chartered Institute of Library and Information Professionals (CILIP, established in 2002). Sheila Corrall can be contacted at s.m.corrall@sheffield.ac.uk. 